\title{
Structure of the weed in Solanaceae Crops in Divo, Sinfra and Djebonoua (Côte D'ivoire)
}

\author{
Sylla Moussa ${ }^{1}$, Diomandé Souleymane ${ }^{1}$, Gué Arsène ${ }^{1}$, Traoré karidia ${ }^{1}$, Soro \\ Dodiomon $^{2}$
}

${ }^{1}$ UFR Agroforesterie, Laboratory of Farm Produce Improvement, Université Jean Lorougnon Guédé, Daloa, Côte d'Ivoire

${ }^{2}$ UFR Biosciences, Laboratory of Botany, Université Félix-Houphouët Boigny, Abidjan, Côte d’Ivoire

\begin{abstract}
The study focused on the structure of the weed of Solanaceae crops (eggplant, chilli and tomato) in Côte d'Ivoire, specifically in Divo, Sinfra and Djebonoua. Its objective is to characterize the weed using botanical and biological parameters. Thus, itinerant surveys were carried out during the 2013 cropping season in Solanaceae crops. This work permits to identify 40 weed species belonging to 32 genera distributed in 20 families. The dominant families are: Euphorbiaceae, Cyperaceae, Poaceae, Asteraceae, Amaranthaceae and Malvaceae. Among these families, the Asteraceae and Poaceae are the most diversified. Biologically, the therophytes clearly dominate this flora followed by nanophanerophytes. The study area has a heterogeneous floristic distribution. The composition, richness and diversity of flora, the biological spectrum and the similarity between the weed of the different towns have been determined in the Solanaceae crops. These data are necessary for the implementation of effective weed management strategies.
\end{abstract}

Keywords-Structure, weed, Solanaceae crops, Côte d'Ivoire.

\section{INTRODUCTION}

Côte d'Ivoire is an agricultural country like most of the countries of sub-Saharan Africa. The agricultural sector employs $66 \%$ of the working population. It contributes to $27 \%$ of the gross domestic product and provides $40 \%$ of export earnings (FAO, 2009). Ivorian agriculture is based on both cash crops (cocoa, coffee, oil palm, etc.), subsistence food crops (cassava, yam, rice, etc.) and vegetables (Anonymous, 2009).

The place occupied by vegetable in the agricultural sector is of capital importance. In 2010, national production of vegetables was estimated at more than 850,000 tons. Market gardening is practiced by a large segment of the population made up of nearly $60 \%$ of women and young people from urban and peri-urban areas (Tano et al., 2011). This activity has a very significant socio-economic impact because it constitutes the main source of income for these people. Various species (tomato, pepper, eggplant, chili, cabbage, lettuce, cucumber, okra, etc.) are grown. Among these species, the Solanaceae crops including eggplant, chilli and tomato is more important because these vegetables are used in almost all dishes in Côte d'Ivoire. Despite its dynamism and its importance in creating wealth for small producers, the production of Solanaceae crops, like other vegetable crops, faces several constraints. These constraints are, among others: the poor sales of production, the low purchase price from producers, the high cost of agricultural inputs and the low productivity of farms due to biotic and abiotic constraints (Anonymous, 2009).

Biotic constraints include weeds, which are a major phytosanitary problem. Indeed, the diversity of weed species within a field under cultivation is a factor favoring the proliferation of animal, fungal, viral and bacterial species. This general increase in harmful factors acts on the health status of the crop and therefore on production (Delos et al., 2007). In addition to this alternative host role for the pathogens that weeds play in crops, they lead them to competition for water, nutrients, light and land use. Crop weeds are also responsible for crop losses. Parker and Fryer (1975) estimate these losses at 5\% in developed countries and more than $25 \%$ in developing countries.

In Côte d'Ivoire, several studies have been carried out on the weed of various cultures. These are, among others, the work of Traoré et al. (2010) who studied the weed under palm groves in the South, Kouamé et al. (2011) who made an inventory of major weeds in rice in the Center and Mahamane (2013) who assessed the noxiousness of weeds of corn in the Center-East. However, works relating to the study of weeds in vegetable in general and in Solanaceae cultivation in particular are rather few or poorly 
disseminated. It is therefore imperative to conduct studies on the structure of these weeds in order to eventually consider effective control strategies. The present work, carried out in the southern half of the country, precisely in the towns of Divo, Sinfra and Djebonoua, aims to contribute to a more current knowledge of the weed of the Solanaceae crops in these towns.

\section{MATERIALS AND METHODS}

Study area

The study was conducted in three towns in Côte d'Ivoire: Divo, Sinfra and Djebonoua (Figure 1).

The first one, Divo, is located in the South of Côte d'Ivoire, less than $200 \mathrm{~km}$ to the North-west of the city of Abidjan (5 $\circ 55^{\prime}$ and $5^{\circ} 844^{\prime} \mathrm{N} ; 5^{\circ} 33^{\prime}$ and $\left.5^{\circ} 37^{\prime} \mathrm{W}\right)$. The climate is subequatorial (Rougerie, 1960). Average annual rainfall is around $1,827 \mathrm{~mm}$ with an average annual temperature of $26.23^{\circ} \mathrm{C}$. The locality belongs to the mesophilic sector of the Guinean domain, characterized by the cleared mesophilic forest (Brou, 2005).

The second one,Sinfra, is located in the Center-West of Côte d'Ivoire in the forest zone. The locality is less than $100 \mathrm{~km}$ southwest of the city of Yamoussoukro $\left(6^{\circ} 37^{\prime}\right.$ and $6^{\circ} 62$ 'N; $5^{\circ} 54^{\prime}$ and $\left.5^{\circ} 97^{\prime} \mathrm{W}\right)$. The climate is humid tropical, it is a transition climate between the equatorial and tropical climate (Rougerie, 1960). Average annual rainfall is around $1,296 \mathrm{~mm}$ with an average annual temperature of $26.68^{\circ} \mathrm{C}$. The vegetation of Sinfra is a semi-deciduous humid forest (Brou, 2005).

And then, the last one, Djebonoua is a town in the Center of Côte d'Ivoire which is located from $15 \mathrm{~km}$ to south of the town of Bouaké $\left(7^{\circ} 30\right.$ 'N, $\left.5^{\circ} 04^{\prime} \mathrm{W} ; 261 \mathrm{~m}\right)$. It belongs to the mesophilic savannah zone (Brou, 2005). The town is subject to the equatorial climate which is a climate of transition between the Guinean and Sudanese type climate (Rougerie, 1960). The average rainfall is $1,100 \mathrm{~mm}$ per year with an average temperature of $25.73{ }^{\circ} \mathrm{C}$.

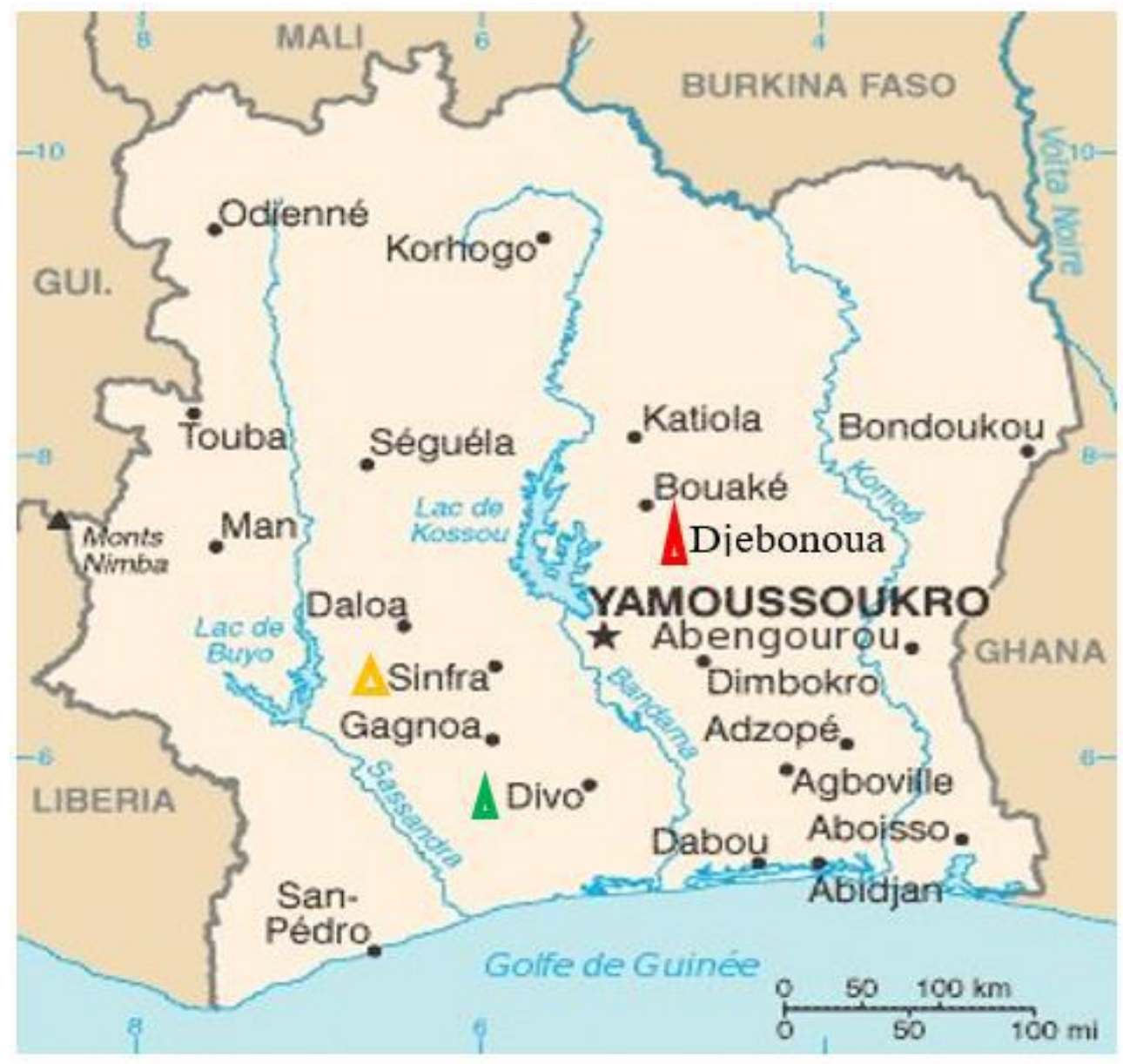

Fig.1: Localisation of the different study areas (Anonyme, 2009).

$\triangle$ Divo

A Sinfra

1 Djebonoua 


\section{STUDY MATERIALS}

The biological material consists of all the weeds encountered in the plots of Solanaceae crops (eggplant, chilli and tomato).

Plant survey cards were used to identify weeds that had emerged.

\section{Floristic inventory}

Weed inventory was carried out during the Solanaceae crop cycle. It was produced using the "field tour" technique. This technique consists in traversing the plot in different directions, noting the presence of each species encountered. The identification of the listed species was carried out using the textbooks of Merlier \& Montegut (1982), Akobundu \& Agyakwa (1989) and Johnson (1997).

Data analysis

Each listed species has been placed in its taxonomic family. It has also been affected by the biological type to which it belongs. The classification model adopted was that of Aké Assi (1984), itself adapted from the Raunkiaer model (1905). The rates of species belonging to the same biological type make it possible to determine the biological spectrum both for each visited town and for the whole study area.

The diversity of the weed was defined by the following two indices:

. the generic diversity index (Gdi), which is the ratio between the number of genera and that of the families listed;

. the specific diversity index (Sdi), which is the ratio between the number of species and that of the genera listed.

These indices give an idea of the degree of plant diversity both for the entire study area and for each of the three inventoried zones and for each of the heigth (8) best represented families.

The coefficient of similarity made it possible to analyze the homogeneity between the lists of weeds from the floristic inventory carried out in the three corresponding areas. It was calculated by opposing the floristic lists of the different localities two by two, according to the formula of Sørensen (1948):

$\mathrm{Cs}=(2 \mathrm{c} * 100) /(\mathrm{a}+\mathrm{b})$

In this formula, $a$ and $b$ represent the number of species listed respectively in the two areas to be compared and c represent the number of species common to the two areas. In theory, Cs varies between 0 and $100 \%$, but in practice these limit values are almost never reached. When $\mathrm{Cs}$ is greater than or equal to $50 \%$, it means that the two compared lists are very close to each other to the point of being assimilated to identical environment. In other words, it indicates that the two concerned areas are floristically homogeneous. On the other hand, when the two lists have different floristic compositions, then Cs is less than $50 \%$.

\section{RESULTS}

Floristic richness

The richness of the flora in the study area was assessed on the basis of the general inventory which was carried out in the three considered towns. The flora listed includes 40 weed species belonging to 32 genera distributed in 20 families. The Dicotyledonous class represents $77.5 \%$ of the species while the Monocotyledonous class is $22.5 \%$. Table 1 lists the weed flora in the study area.

As for Table 2, it shows the distribution of species according to the major taxonomic levels in each locality of the study area. The same table indicates that some species are subservient to each of the inventoried town; there are 2; 6 and 11 species respectively in Divo, Sinfra and Djebonoua. In addition, 5 species are common to the three inventoried localities.

Within the families identified in the study area, 6 families alone contain $62.5 \%$ of the species distributed in 18 genera. These are Euphorbiaceae, Cyperaceae, Poaceae, Asteraceae, Amaranthaceae and Malvaceae. These families are also the best represented in each of the three towns (Table 3).

Table 1. List of the weed inventoried in the study area and their presene and abscence in the different study towns

\begin{tabular}{|c|c|c|c|c|c|c|c|}
\hline \multirow[t]{2}{*}{$\mathrm{N}^{\circ}$} & \multirow[t]{2}{*}{ Species Names } & \multirow[t]{2}{*}{ Families } & \multirow[t]{2}{*}{$\mathrm{Cl}$} & \multirow[t]{2}{*}{ BT } & \multicolumn{3}{|c|}{ Towns } \\
\hline & & & & & DI & SI & DJ \\
\hline 1 & Acalypha ciliata Forssk. & Euphorbiaceae & $\mathrm{D}$ & $\mathrm{Th}$ & - & + & - \\
\hline 2 & Ageratum conyzoides L. & Asteraceae & $\mathrm{D}$ & Th & + & + & + \\
\hline 3 & Amaranthus spinosus L. & Amaranthaceae & $\mathrm{D}$ & Th & + & + & - \\
\hline 4 & Amaranthus viridis L. & Amaranthaceae & $\mathrm{D}$ & $\mathrm{Th}$ & + & + & - \\
\hline 5 & Bidens pilosa $\mathrm{L}$. & Compositae & $\mathrm{D}$ & $\mathrm{Th}$ & - & + & - \\
\hline
\end{tabular}




\begin{tabular}{|c|c|c|c|c|c|c|c|}
\hline 6 & Boerhavia diffusa $\mathrm{L}$. & Nyctaginaceae & $\mathrm{D}$ & np & - & - & + \\
\hline 7 & Calopogonium muсunoides Desv & Papilionoideae & $\mathrm{D}$ & $\mathrm{H}$ & + & + & - \\
\hline 8 & Cassia obtusifolia $\mathrm{L}$. & Caesalpinioideae & $\mathrm{D}$ & np & + & + & - \\
\hline 9 & Cassia occidentalis L. & Leguminosae & $\mathrm{D}$ & $\mathrm{np}$ & - & + & - \\
\hline 10 & Celosia trigyna $\mathrm{L}$. & Amaranthaceae & $\mathrm{D}$ & $\mathrm{Th}$ & + & + & - \\
\hline 11 & Centrosema pubescens Benth & Papilionoideae & $\mathrm{D}$ & $\mathrm{mp}$ & + & + & - \\
\hline 12 & Chromolaena odorata (L.) R.M King et H. Robinson & Asteraceae & $\mathrm{D}$ & $\mathrm{np}$ & + & + & + \\
\hline 13 & Commelina benghalensis L. & Commelinaceae & $\mathrm{D}$ & $\mathrm{Ch}$ & - & + & - \\
\hline 14 & Crotalaria retusa (Linnaeus.) & Fabaceae & $\mathrm{D}$ & $\mathrm{np}$ & + & + & - \\
\hline 15 & Croton hirtus L'Hérit & Euphorbiaceae & $\mathrm{D}$ & $\mathrm{Th}$ & + & + & + \\
\hline 16 & Cyperus difformis $\mathrm{L}$. & Cyperaceae & M & $\mathrm{Th}$ & - & - & + \\
\hline 17 & Cyperus esculentus Linnaeus. & Cyperaceae & M & G & + & + & - \\
\hline 18 & Dactyloctenium aegyptium (Linnaeus.) Palisot de Beauvois & Poaceae & M & $\mathrm{H}$ & - & - & + \\
\hline 19 & Digitaria horizontalis Willdenow & Poaceae & M & $\mathrm{Th}$ & - & - & + \\
\hline 20 & Euphorbia heterophylla Linnaeus & Euphorbiaceae & $\mathrm{D}$ & $\mathrm{Th}$ & - & - & + \\
\hline 21 & Euphorbia hirta (L.) Millsp & Euphorbiaceae & $\mathrm{D}$ & $\mathrm{Ch}$ & - & - & + \\
\hline 22 & Euphorbia hyssopifolia $\mathrm{L}$. & Euphorbiaceae & $\mathrm{D}$ & $\mathrm{Th}$ & - & - & + \\
\hline 23 & Fimbristylis littoralis Gaud. & Cyperaceae & M & Th & - & + & - \\
\hline 24 & Mariscus cylindristachyus Steudel & Cyperaceae & M & $\mathrm{H}$ & + & - & + \\
\hline 25 & Mariscus flabelliformis Kunth var. flabelliformis & Cyperaceae & M & $\mathrm{H}$ & + & + & - \\
\hline 26 & Mimosa pudica $\mathrm{L}$. & Mimosoideae & $\mathrm{D}$ & $\mathrm{np}$ & - & - & + \\
\hline 27 & Mollugo nudicaulis Lamarck. & Molluginaceae & $\mathrm{D}$ & $\mathrm{Th}$ & - & - & + \\
\hline 28 & Momordica charantia L. & Cucurbitaceae & $\mathrm{D}$ & $\mathrm{Th}$ & + & + & - \\
\hline 29 & Oldenlandia corymbosa $\mathrm{L}$. & Rubiaceae & $\mathrm{D}$ & $\mathrm{Ch}$ & - & - & + \\
\hline 30 & Paspalum conjugatum Berg. & Poaceae & M & $\mathrm{Ch}$ & - & + & - \\
\hline 31 & Phyllanthus amarus Schum. et Thonn. & Euphorbiaceae & $\mathrm{D}$ & $\mathrm{np}$ & + & + & + \\
\hline 32 & Setaria barbata (Lam.) Kunth & Poaceae & M & $\mathrm{H}$ & - & + & - \\
\hline 33 & Sida acuta Burm & Malvaceae & $\mathrm{D}$ & $\mathrm{np}$ & - & + & - \\
\hline 34 & Sida urens L. & Malvaceae & $\mathrm{D}$ & $\mathrm{np}$ & + & + & - \\
\hline 35 & Sida rhombifolia $\mathrm{L}$. & Malvaceae & $\mathrm{D}$ & $\mathrm{np}$ & + & + & - \\
\hline 36 & Solanum nigrum $\mathrm{L}$. & Solanaceae & $\mathrm{D}$ & np & - & - & + \\
\hline 37 & Spigelia anthelmia $\mathrm{L}$. & Loganiaceae & $\mathrm{D}$ & $\mathrm{Th}$ & + & - & - \\
\hline 38 & Spilanthes uliginosa $\mathrm{Sw}$. & Compositae & $\mathrm{D}$ & Th & + & - & - \\
\hline 39 & Trianthema portulacastrum L. & Asteraceae & $\mathrm{D}$ & $\mathrm{Th}$ & + & + & + \\
\hline 40 & Tridax procumbens Linnaeus. & Asteraceae & $\mathrm{D}$ & $\mathrm{Ch}$ & + & + & - \\
\hline
\end{tabular}

+ : present ; - : absent ; Cl : class ; TB : biological type ; M : Monocotyledon ; D : Dicotyledon ; DI : Divo ; SI : Sinfra ; DJ : Djebonoua ; mp : microphanerophyte ; np : nanophanerophyte ; Ch : chamephyte ; H : hemicryptophyte ; G : geophyte ; Th : therophyte. 
Table 2. Weed number according to the great taxonomic levels in each study town

\begin{tabular}{lcccc}
\hline Areas & Families & Genera & Species & Local species \\
Divo & 11 & 18 & 21 & 2 \\
Sinfra & 13 & 22 & 25 & 6 \\
Djebonoua & 9 & 16 & 17 & 11 \\
\hline
\end{tabular}

Gdi : generic diversity index; Sdi : specific diversity index.

Table 3. Number of the genera and species of the best represented families in each study zone with their specific diversity index.

\begin{tabular}{|c|c|c|c|c|c|c|c|c|c|c|c|c|}
\hline \multirow{3}{*}{ Families } & \multicolumn{12}{|c|}{ Distribution according the towns and the study area } \\
\hline & \multicolumn{3}{|c|}{ Divo } & \multicolumn{3}{|c|}{ Sinfra } & \multicolumn{3}{|c|}{ Djebonoua } & \multicolumn{3}{|c|}{ Study area } \\
\hline & G & $\mathrm{S}$ & Sdi & G & $\mathrm{S}$ & Sdi & G & $\mathrm{S}$ & Ids & G & $\mathrm{S}$ & Sdi \\
\hline Euphorbiaceae & 2 & 2 & 1,00 & 3 & 3 & 1,00 & 3 & 5 & 1,66 & 4 & 6 & 1,50 \\
\hline Cyperaceae & 2 & 3 & 1,50 & 3 & 3 & 1,00 & 2 & 2 & 1,00 & 3 & 5 & 1,66 \\
\hline Poaceae & - & - & - & 2 & 2 & 1,00 & 2 & 2 & 1,00 & 4 & 4 & 1 \\
\hline Asteraceae & 4 & 4 & 1,00 & 4 & 4 & 1,00 & 3 & 3 & 1,00 & 4 & 4 & 1 \\
\hline Amaranthaceae & 2 & 3 & 1,50 & 2 & 3 & 1,50 & - & - & - & 2 & 3 & 1,5 \\
\hline Malvaceae & 1 & 2 & 2,00 & 1 & 3 & 3,00 & - & - & - & 1 & 3 & 3 \\
\hline
\end{tabular}

$\mathrm{G}$ : genus ; $\mathrm{S}$ : species ; Sdi : specific diversity index ; - : absent.

Spectrum of biological types

The main biological types encountered in this study are the following: therophytes, nanophanerophytes, hemicryptophytes, chamelephtes, geophytes and microphanerophytes. The proportions of the biological types of the species identified in the three localities (Divo, Sinfra and Djebonoua) are illustrated in Figures 2, 3 and 4. Figure 5 , synthesis of the previous three Figures, corresponds to the biological spectrum of the study area. It appears that in the three inventoried towns, as at the level of the synthetic spectrum, two biological types are particularly dominant. These are therophytes and nanophanerophytes which, in any case, contribute together for at least $68 \%$. Next come the hemicryptophytes and chamelephtes. The other biological types (geophytes and microphanerophytes) have relatively small proportions. The latter were not observed in the area of Djebonoua. By combining all the phanerophytes with the therophytes, an average cumulative contribution of around $71 \%$ is reached.

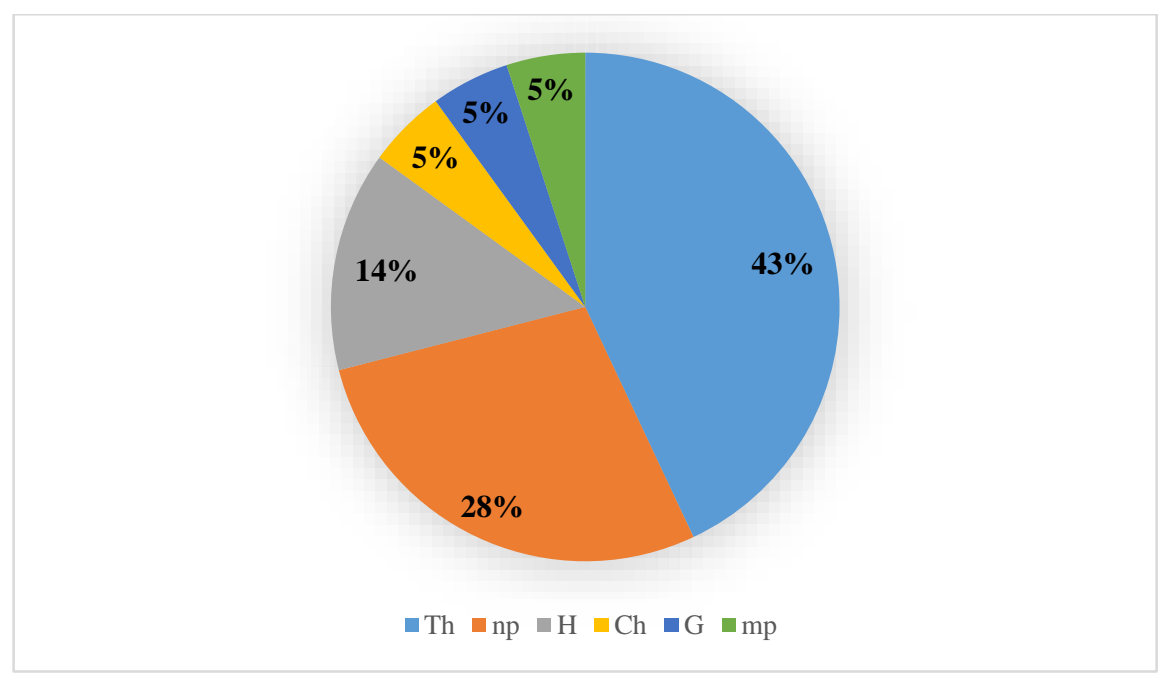

Fig.2. Weed biological types spectrum in Divo.

Th : therophyte ; np : nanophanerophyte ; $\mathrm{H}$ : hemicryptophyte ; Ch : chamephyte ; G : geophyte ; mp : microphanerophyte. 
International Journal of Environment, Agriculture and Biotechnology, 5(3)

May-Jun, 2020 / Available: https://ijeab.com/

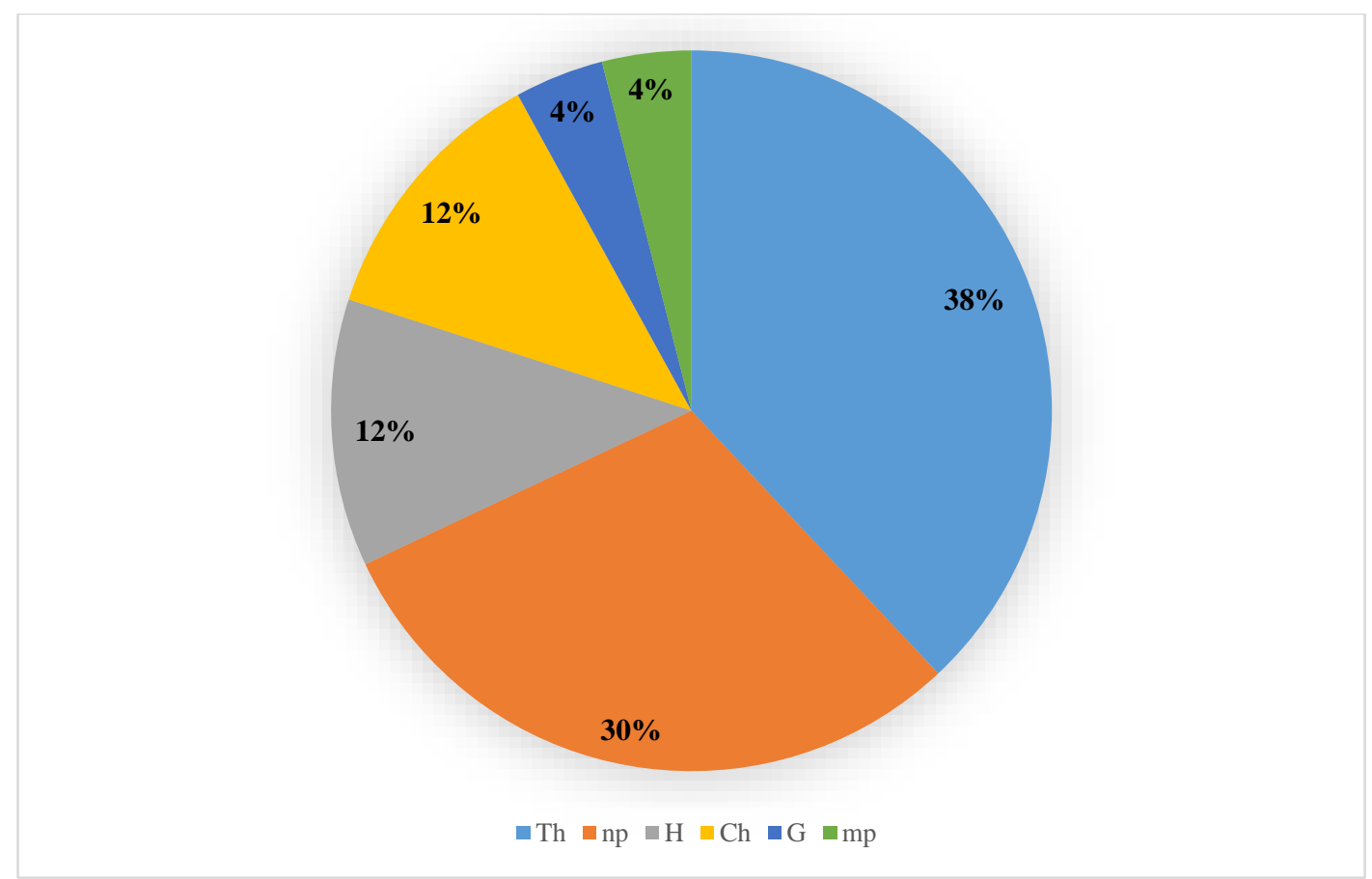

Fig.3. Weed biological type spectrum in Sinfra.

Th : therophyte ; np : nanophanerophyte ; $\mathrm{H}$ : hemicryptophyte ; Ch : chamephyte ; G : geophyte ; mp : microphanerophyte.

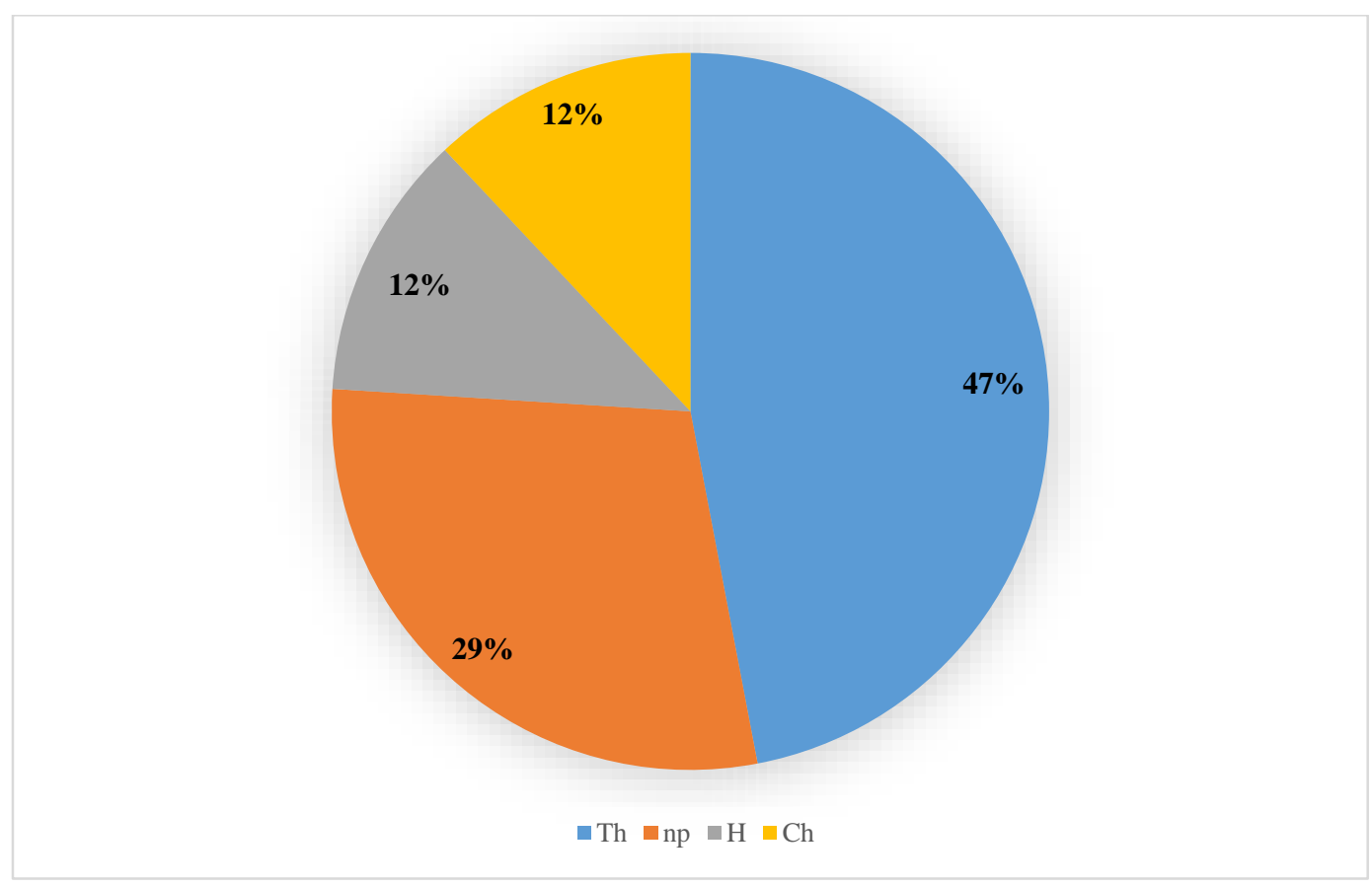

Fig.4. Weed biological type spectrum in Djebonoua.

Th : therophyte ; np : nanophanerophyte ; $\mathrm{H}$ : hemicryptophyte $; \mathrm{Ch}$ : chamephyte. 


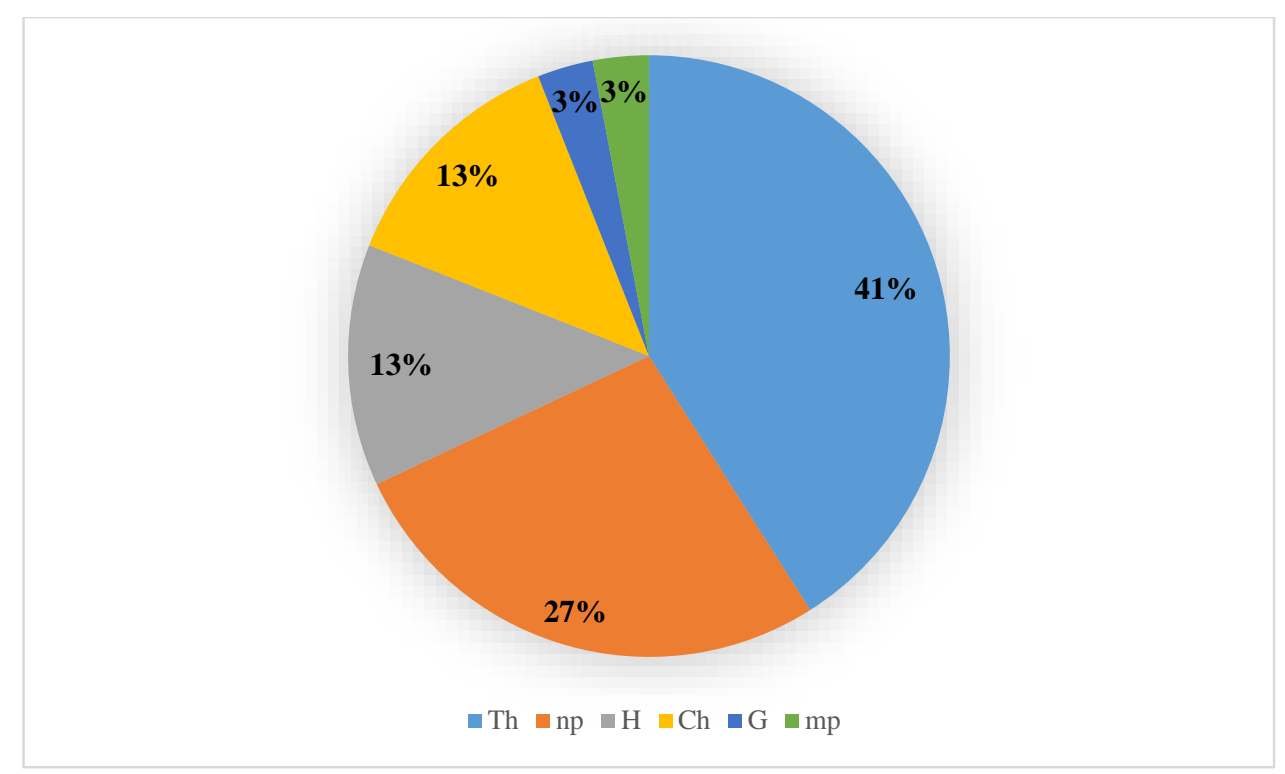

Fig.5. Weed biological type spectrum of the study area.

Th : therophyte ; np : nanophanerophyte ; H : hemicryptophyte ; Ch : chamephyte ; G : geophyte ; mp : microphanerophyte.

Floristic diversity

The various index of floristic diversity determined are relatively low; around 1.60 and 1.25 , respectively, for generic diversity and specific diversity for all the three towns. This shows that there is a great diversity within this flora. The town of Divo is rich in genus with a generic diversity index of 1.63 while that of Djebonoua is rich in species with a specific diversity index of about 1 (Table 4).

When we consider each of the six families best represented in each area, the Asteraceae and Poaceae families which occupy the third positions in number of species are the most diverse, with a specific diversity index of 1 for each family. They are followed by those of Euphorbiaceae and Amaranthaceae which have a specific diversity index of 1.50 each. The Euphorbiaceae family, in addition to being the richest in species, has a large number of genera. The Malvaceae family has the highest specific diversity index, which is 3 ; it therefore appears to be the least diversified of the six selected families (Table 3 ).

Table 4. Diversity index of the weeds inventoried in each part of the study area.

\begin{tabular}{lcc}
\hline Towns & $\begin{array}{l}\text { Generic diversity } \\
\text { index }\end{array}$ & $\begin{array}{l}\text { Specific diversity } \\
\text { index }\end{array}$ \\
\hline Divo & 1,63 & 1,16 \\
Sinfra & 1,69 & 1,13 \\
Djebonoua & 1,77 & 1,06 \\
Study areas & 1,60 & 1,25 \\
\hline
\end{tabular}

\section{Similarity of weeds}

The coefficient of similarity for all the towns is around $44 \%$, this value less than $50 \%$ means that the three inventoried localities have different floristic compositions. But the analysis of the three couples obtained by confronting the flora of the three localities in pairs (Table 5) shows that:

- the localities of Divo and Sinfra are floristically homogeneous because the coefficient of similarity of the species is $76.59 \%$;

- the weed of the locality of Divo is different from that of Djebonoua with a coefficient of similarity of the species which is $31.57 \%$;

- the localities of Sinfra and Djebonoua are floristically heterogeneous with a coefficient of similarity of the species which is around $23.25 \%$.

Table 5. Coefficients of similarity obtained from the different towns of the study area.

\begin{tabular}{lcccc}
\hline \multirow{2}{*}{ Couples of towns } & \multicolumn{3}{c}{ Number of species } & \multirow{2}{*}{ Cs $(\%)$} \\
\cline { 2 - 4 } & $\mathrm{a}$ & $\mathrm{b}$ & $\mathrm{c}$ & \\
\hline Divo-Sinfra & 21 & 26 & 18 & 76,59 \\
Divo-Djebonoua & 21 & 17 & 6 & 31,57 \\
Sinfra-Djebonoua & 26 & 17 & 5 & 23,25 \\
\hline
\end{tabular}

$\mathrm{a}:$ number of species belonging to the list $\mathrm{A} ; \mathrm{b}:$ number of species belonging to the list B ;

$\mathrm{c}$ : number of species belonging to the list $\mathrm{C}$; $\mathrm{Cs}$ : Coefficient of similarity 


\section{DISCUSSION}

The weed of the Solanaceae crops (eggplant, peppers and tomatoes) identified in our study area is quantitatively not very important, compared to that inventoried by Boraud (2000), Ipou Ipou (2005) and Traoré et al. (2010) respectively in sugar cane, cotton growing and palm grove. The difference observed in the level of floristic richness could be explained by the area of the inventoried plots. In fact, in Solanaceae crops the field area is smaller (on average $0.25 \mathrm{ha}$ ) whereas in other crops the areas are larger because it is industrial crops.

The predominance of Dicotyledons in favor of Monocotyledons in the different towns of the study area is consistent with the observations made by Bassene (2012) and Mahamane (2013), respectively, in the South of the groundnut basin in Senegal and in the Center-East of Côte d'Ivoire. This taxonomic distribution shows a certain monotony in the floristic diversity within weeds in tropical Africa (Marnotte, 2000).

Analysis of the results shows that the locality of Sinfra differs from the two other localities inventoried by its relatively high floristic richness at all taxonomic levels. But concerning the species subservient to the various towns, it is the town of Djebonoua which is characterized by rich flora. According to the indices of floristic diversity, it appears that, the locality of Divo is richer in genus while that of Djebonoua is richer in species.

This study revealed that the families of Euphorbiaceae, Cyperaceae, Poaceae, Asteraceae, Amaranthaceae and Malvaceae make up $62.50 \%$ of the listed species. Apart from the Amaranthaceae family, these families are the most represented in cotton farming in the North of Côte d'Ivoire (Aman Kadio, 2004). In addition, with the exception of Amaranthaceae and Malvaceae, the four other families richest in species in Solanaceae crops in the area are among the 10 families with the most species considered major weeds globally (Akobundu \& Agyakwa, 1989). Maillet (1981) explains the predominance of families with numerous species by their adaptation to very different environments. The Poaceae and Asteraceae families which occupy the third positions in number of species are the most diverse. This result is in agreement with that obtained in palm grove by Traoré et al. (2010) in the South of the Côte d'Ivoire.

The spectrum of biological types indicates that, whatever the locality, the therophytes and nanophanerophytes (with a predominance of the first) are the most representative (68\%) of the weed flora of Solanaceae crops. These results are confirmed by those of Aman Kadio (2004) in cotton farming. The situation can also be explained by the fact that in agricultural practices in intertropical Africa, in general, the therophytes and nanophanerophytes, are put in place from the first work of preparing the plots to be cultivated, while most weeds belonging to other biological types, in particular mesophanerophytes, microphanerophytes and geophytes, are very quickly eliminated by plowing or weeding (Aman Kadio, 1973). The predominance of therophytes is explained by their adaptations to cultivated environments, due to their great capacity for sexual or vegetative multiplication, as well as the very high germinative power of their seeds. In addition, this exceptional dynamic of therophytes is all the more increased as the cultivated plot is well exposed to the sun, since most of these plants are heliophilous species (Aman Kadio, 1973 and 1978).

Comparing the floristic lists, using the coefficient of similarity method, reveals that the value obtained for all three towns is less than $50 \%$. This indicates that the study area has a heterogeneous floristic composition. The heterogeneity of the weed could be due to the geographical location of each studied town. However, by comparing the floristic lists coming from each of the three towns constituting the study area, we can see that the values of the similarity coefficients obtained are not always less than $50 \%$. These results indicate that the value of the coefficient of similarity between the lists of weeds in the towns of Divo and Sinfra is $76.59 \%$. This means that the two towns are floristically homogeneous. The two towns have an identical floristic procession because they are all located in a forest area.

\section{CONCLUSION}

This study, carried out on the Solanaceae crops (eggplant, chilli and tomato) of Divo, Sinfra and Djébonoua, in Côte d'Ivoire, identified 40 weed species belonging to 32 genera in 20 families. The Dicotyledonous class represents $77.5 \%$ of the species while the Monocotyledonous class is $22.5 \%$. This flora is characterized by the predominance of Euphorbiaceae (15\%), Cyperaceae (12.5\%), Poaceae (10\%), Asteraceae (10\%), Amaranthaceae $(7.5 \%)$ and Malvaceae (7.5\%). Among these families, the Asteraceae and Poaceae are the most diverse. On a biological level, the therophytes clearly dominate this weed with $41 \%$, they are followed by nanophanerophytes which represent $27 \%$.

Nevertheless, the hemicryptophytes and the chamephytes are present even if they are less represented with $13 \%$ each. Among the three inventoried towns, that of Divo is the richest in genus while that of Djebonoua is richest in species. The comparison of the floristic lists coming from these three towns reveals a floristic heterogeneity of the study area. 
However, the locality of Divo and Sinfra are floristically homogeneous. However, each town has a floristic procession which is particularly subservient to it.

\section{ACKNOWLEDGMENT}

The authors are gratefull to ANAFE (African Network for Agriculture, Agroforestery and Natural Resources) for its financial assistance which permits the realization of this work.

\section{REFERENCES}

[1] Aké Assi L., 1984. Flore de la Côte d'Ivoire. Etude descriptive et biogéographique, avec quelques notes ethnobotaniques. Thèse de Doctorat d'Etat, Université d'Abidjan, Côte d'Ivoire. 6 vol., 1206 p

[2] Akobundu I.O., Agyakwa C.W., 1989. Guide des adventices d'Afrique de l'Ouest. IITA, Ibadan, Nigeria, $522 \mathrm{p}$.

[3] Aman Kadio G., 1973. Inventaire floristique dans une parcelle de forêt défrichée. D. E. A. Fac. Sc. Univers. d'Abidjan, 50 p.

[4] Aman Kadio G., 1978. Flore et végétation des adventices dans l'hévéaculture en basse Côte d'Ivoire (Station expérimentale de l'IRCA). Etude écologique : dynamique et structure. Thèse de spécialité, écologie végétale. Fac. Sc., Univers. d'Abidjan, $200 \mathrm{p}$.

[5] Aman Kadio G., Ipou Ipou J. et Touré Y., 2004. La flore des adventices des cultures cotonnières de la région du Worodougou, au Nord-ouest de la Côte d'Ivoire. Agronomie Africaine, 16 (1) : 1-14.

[6] Anonymous, 2009. République de Côte d'Ivoire : Rapport national sur l'état des ressources phytogénétiques pour l'alimentation et l'agriculture, $65 \mathrm{p}$.

[7] Bassene C., Mbaye M.S., Kane A., Diangar S., Noba K., 2012. Flore adventice du maïs (Zea mays L.) dans le sud du Bassin arachidier (Sénégal) : structure et nuisibilité des espèces. Journal of Applied Biosciences, 59 : 4307- 4320.

[8] Boraud N.K.M., 2000. Etude floristique et phytoécologique des adventices des complexes sucriers de Ferké 1 et 2, de Borotoukoro et de Zuénoula, en Côte d'Ivoire. Doctorat $3^{\text {ème }}$ cycle,

[9] UFR Biosciences, Univ. Cocody, Côte d'Ivoire, 181 p.

[10] Brou Y. T., 2005.- Climat, mutations socio-économiques et paysages en Côte d'Ivoire. Mémoire de synthèse des activités scientifiques présenté en vue de l'obtention de l'habilitation à diriger des recherches, Université des Sciences et Technologies, Lille, France, 212 p.

[11] Delos M., Eychenne N., Croin V., Cariou L., 2007. Analyse des interactions entre la flore adventices des parcelles cultivées et les autres bioagresseurs de la culture. AFPP. 20ème conférence du COLUMA. Journée internationales sur la lutte contre les mauvaises herbes, Dijon (France), 11-12 décembre, $7 \mathrm{p}$.

[12] FAO, 2009. Annuaire statistique. http://faostat.fao.org, consulté le 07/04/2013.
[13] Ipou Ipou J., 2005. Biologie et écologie de Euphorbia heterophylla L. (Euphorbiaceae) en culture cotonnière, au Nord de la Côte d'Ivoire. Thèse de l'Université de CocodyAbidjan, Côte d'Ivoire, 195 p.

[14] Johnson D. E., 1997. Les adventices en riziculture en Afrique de l'Ouest. ADRAO, $312 \mathrm{p}$.

[15] Kouamé K.F., Ipou Ipou J., Touré A., N'Guessan K.E., 2011. Major weeds of rice agro-ecosystems in Côte d'Ivoire. Agriculture and Biology Journal of North America, 2(9) : 1317-1325.

[16] Mahamane A., 2013. Effet de la densité de Rottboellia cochinchinensis (Loureiro) W. Clayton (Poaceae) sur le maïs à M'Bahiakro (Centre-Est de la Côte d'Ivoire). Mémoire de DEA, UFR Biosciences, Université Félix Houphouët Boigny (Abidjan-Côte d'Ivoire), $51 \mathrm{p}$.

[17] Maillet J., 1981. Evolution de la flore adventice dans le Montpellierais sous la pression des techniques culturales. Thèse de l'Université de Montpellier II, France, 200 p.

[18] Marnotte P., 2000. La gestion de l'enherbement et l'emploie des herbicides dans les systèmes de culture en zone Soudanosahélienne en Afrique de l'Ouest et du Centre. Formation du CIRAD. CIRAD-CA-G.E.C.- AMATROP, 66 p.

[19] Merlier H., Montegut J., 1982. Adventices Tropicales. Ministère des Relations extérieures, Coopération et développement, France, 490 p.

[20] Parker C. and Fryer J. D., 1975. Lutte contre les mauvaises herbes occasionnant d'importantes réductions des ressources alimentaires mondiales. FAO. Bull Phyto, 23 (3/4) : 84-98

[21] Raunkiaer S. 1905. Types biologiques pour la géographie botanique. Bull. Acad. R. Sc. Danemark, 5: 347-437.

[22] Rougerie G., 1960. Le façonnement actuel des modelés en Côte d'Ivoire forestière. Thèse de

[23] Doctorat ès Lettres. Paris, Mém. IFAN 58, 542 p.

[24] Sorensen T., 1948. A method of establishing group of equal amplitude in plants

[25] sociology based on similary of species content. Det Kongelige danske videnkarbernes. Biologiske Skrifter, 5 (4) : 1-34.

[26] Tano B.F., Abo K., Dembélé A. et Fondio L., 2011. Système de production et pratiques à risque en agriculture urbaine : cas du maraîchage dans la ville de Yamoussoukro en Côte d'Ivoire. International Journal of Biological and Chemical Sciences, 5 (6) : 2317-2329.

[27] Traoré K., Soro D., Pené C.B., et Aké S., 2010. Flore adventice sous palmeraie, dans la zone de savane incluse à Dabou, Basse Côte d'ivoire. Agronomie Africaine, 22 (1) : 21 32. 